\title{
Methodology for Conceptualization of Customizable Virtual Workspaces
}

\author{
Dario Rodriguez and Ramón Garcia-Martínez \\ Research Laboratory on Virtual Spaces for Collaborative Work \\ Information Systems Research Group, National University of Lanus \\ Remedios de Escalada, Buenos Aires, Argentina \\ \{darodriguez,rgarcia\}@unla.edu.ar
}

\begin{abstract}
The improvement on evolution of quality of communications based on Internet technology is the base of the trend of development of free Virtual Workspaces. As an emerging family of applications to be developed, needs tools for conceptualizing process as input of design processes. This paper introduces a conceptualization process of virtual workspaces oriented to strictly cover specific interaction needs, and proposes a set of techniques where each of these techniques is associated to development of each conceptualization task of presented process.
\end{abstract}

Keywords: Virtual workspace, conceptualization process, formalisms for modeling human interactions, techniques to develop formalisms.

\section{Introduction}

Virtual spaces dedicated to collaborative work (VSCW) are intended to facilitate mediation inside teams whose members are not physically contiguous, and have to develop a conceptual object (for example: research, project development, software, technical articles, reports, documentation of building design, business plans, corporative investment plans, among others). The VSCW must satisfy the requirement of keeping and documenting the different versions of the conceptual object that is being developed by the collaborative working team; leaving a record of the evolution from the agreement among the members of the working group since initial specifications of the conceptual object until its final stage of development.

There are some proposals for conceptual modelling notations of aspects of group work [1-2]. Recently, there has been proposed [3] a set of interaction modeling formalisms among group members within a virtual collaborative work space that may be briefly describe as follows: [a] Table Concept-Category-Definition: Its function is to represent the factual knowledge of the conceptual model of group dynamics; [b] Cases of Interaction: are used to modelize the interactions between two actors, [c] Diagrams of Group Interaction: are used to modelize, in an integrated way, interactions among all actors considered in the modeling process; [d] Interaction Procedures: are used to describe the composition of interactions among the actors made for the development of an object; [e] Sequence Diagram of Group Dynamics: are used to express the group dynamics among the actors in the timeline imposed by 
the procedures of interaction; [e] Diagram of Conceptual Object Development: are digraphs with two types of nodes: the "conceptual objects" and the "transformations" which represent the action that must to be performed to make evolve the "conceptual object" from a level of development into another.

This paper is structured as follows, in section 2 is defined the problem of conceptualization of virtual workspaces, in section 3 is proposed a conceptualization methodology (the process, the tasks and the conceptualization techniques for each task of the process), in section 4 is presented a concept proof, and in section 5 is summarized preliminary conclusions and future research.

\section{Definition of the Problem}

Several authors [4-8] from a wide range of fields (users and developers) have pointed out in different ways that state of conceptual modeling of virtual work group is characterized by the following limitations: [a] lack of techniques to derive conceptual models (and absence of corresponding formalisms) of interaction among group members and among them and objects; from the description of the workspace and developed tasks within it; and [b] lack of processes that allow deriving the architecture of the virtual space designed for the particular needs of a workgroup, from conceptual models which describe the interactions among its members and objects. Regarding these limitations, we introduce a conceptualization process of virtual workspaces, and propose a set of techniques where each of these techniques is associated to development of each conceptualization task of presented process.

\section{Proposed Conceptualization Methodology}

The conceptualization methodology of virtual space oriented to collaborative work (VSCW) proposed in this paper is structured by a process with three phases: Phase of Static Conceptualization of VSCW, whose objective is focused on the characterization of the concepts related to Virtual Workspace and its categorization in: Actors, Objects and Interactions; Phase of Dynamic Conceptualization of VSCW, whose objective is focused on the characterization of the interactions between actors and between actors and objects, giving a comprehensive view of the interactions streaming along timeline; Phase of Modeling of VSCW, whose objective is to identify the features that should have the virtual workspace to support the interactions among actors, and among actors and objects, identifying which components should give support to each type of interaction. Each phase consists of tasks with an associated technique to develop each one; and a set of products that can act as elements of input and / or output of a given task [9]. Each task defines a set of products as insumes, and generates a set of products as output of its development. The products are partial conceptualizations of the description of workspace and interactions among persons in it. The partial conceptualizations are based on formalisms introduced in [3]. Figure 1 presents the interaction among phases, tasks and products, and shows the flow of products supplied to tasks and the products that are the result of the different accomplished tasks. A summary of tasks, the techniques that develop them, and products used as input or output for each task (technique) is shown in Table 1. 


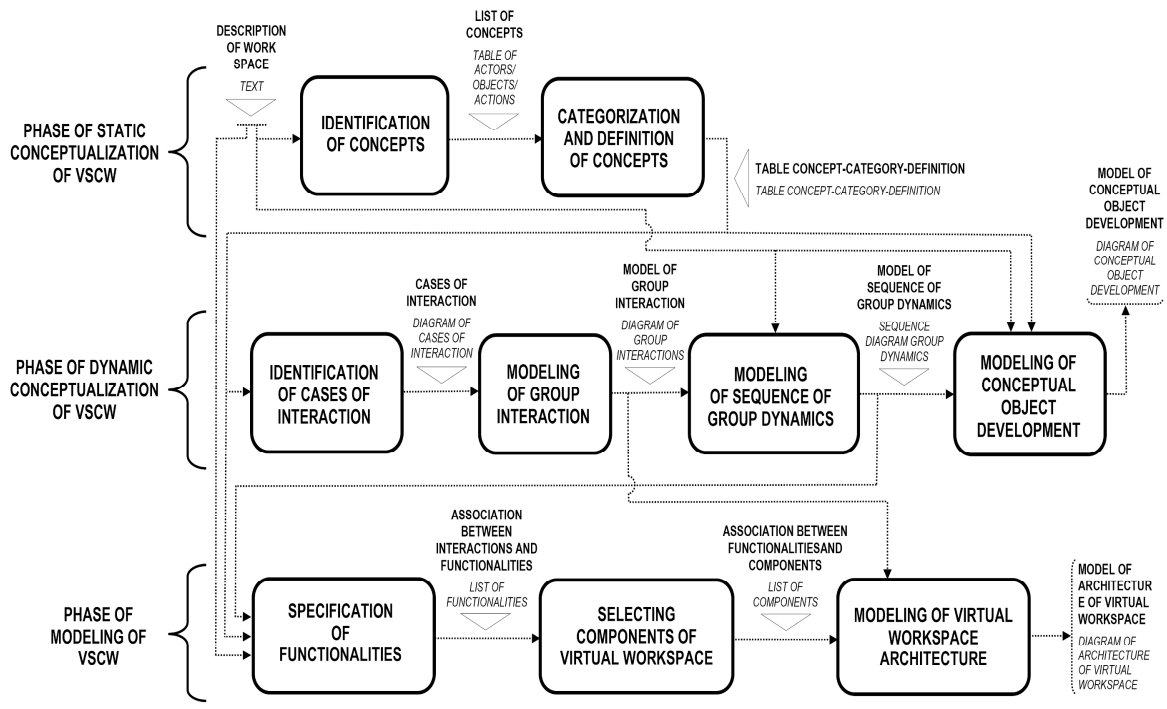

Fig. 1. Interaction among phases, tasks and products

Table 1. Summary Table of Tasks, Techniques and Products (Input or Output)

\begin{tabular}{|c|c|c|c|c|c|}
\hline & FASE & TASK & TECHNIQUE & $\begin{array}{l}\text { MODELING FORMALISM(S) } \\
\text { FOR INPUT PRODUCT(S) }\end{array}$ & $\begin{array}{l}\text { MODELING FORMALISM } \\
\text { FOR OUTPUT PRODUCT }\end{array}$ \\
\hline \multirow{14}{*}{ 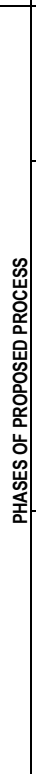 } & \multirow{2}{*}{ 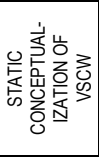 } & $\begin{array}{l}\text { Identification of } \\
\text { Concepts }\end{array}$ & $\begin{array}{l}\text { Technique for Identification } \\
\text { of Concepts in Text (see } \\
\text { Table 2) }\end{array}$ & Description of Work Space & List of Concepts \\
\hline & & $\begin{array}{l}\text { Categorization and } \\
\text { Definition of Concepts }\end{array}$ & $\begin{array}{l}\text { Technique to Build Table } \\
\text { Concept-Category-Definition } \\
\text { (see Table 3) }\end{array}$ & List of Concepts & $\begin{array}{l}\text { Table Concept-Category- } \\
\text { Definition }\end{array}$ \\
\hline & \multirow{7}{*}{ 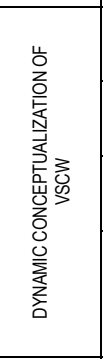 } & $\begin{array}{l}\text { Identification of Cases } \\
\text { of Interaction }\end{array}$ & $\begin{array}{l}\text { Technique to Build Diagram } \\
\text { of Cases of Interaction (see } \\
\text { Table 4) }\end{array}$ & $\begin{array}{l}\text { Table Concept-Category- } \\
\text { Definition }\end{array}$ & $\begin{array}{l}\text { Diagram of Cases of } \\
\text { Interaction }\end{array}$ \\
\hline & & $\begin{array}{l}\text { Modeling of Group } \\
\text { Interaction }\end{array}$ & $\begin{array}{l}\text { Technique to Build Diagram } \\
\text { of Group Interactions (see } \\
\text { Table 5) }\end{array}$ & $\begin{array}{l}\text { Diagrams of Cases of } \\
\text { Interaction }\end{array}$ & $\begin{array}{l}\text { Diagram of Group } \\
\text { Interactions }\end{array}$ \\
\hline & & \multirow{2}{*}{$\begin{array}{l}\text { Modeling of Sequence } \\
\text { of Group Dynamics }\end{array}$} & \multirow{2}{*}{$\begin{array}{l}\text { Technique to Build } \\
\text { Sequence Diagram Group } \\
\text { Dynamics (see Table 6) }\end{array}$} & Description of Work Space & \multirow{2}{*}{$\begin{array}{l}\text { Sequence Diagram } \\
\text { Group Dynamics }\end{array}$} \\
\hline & & & & Diagram of Group Interaction & \\
\hline & & \multirow{3}{*}{$\begin{array}{l}\text { Modeling of } \\
\text { Conceptual Object } \\
\text { Development }\end{array}$} & \multirow{3}{*}{$\begin{array}{l}\text { Technique to Build Diagram } \\
\text { of Conceptual Object } \\
\text { Development (see Table 7) }\end{array}$} & Description of Work Space & \multirow{3}{*}{$\begin{array}{l}\text { Diagram of Conceptual } \\
\text { Object Development }\end{array}$} \\
\hline & & & & $\begin{array}{l}\text { Table Concept-Category- } \\
\text { Definition }\end{array}$ & \\
\hline & & & & $\begin{array}{l}\text { Sequence Diagram Group } \\
\text { Dynamics }\end{array}$ & \\
\hline & \multirow{5}{*}{ 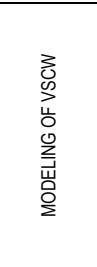 } & \multirow{3}{*}{$\begin{array}{l}\text { Specification of } \\
\text { Functionalities }\end{array}$} & \multirow{3}{*}{$\begin{array}{l}\text { Technique for Association } \\
\text { between Interactions and } \\
\text { Functionalities (see Table 8) }\end{array}$} & Description of Work Space & \multirow{3}{*}{$\begin{array}{l}\text { Table of Association } \\
\text { between Interactions and } \\
\text { Functionalities }\end{array}$} \\
\hline & & & & $\begin{array}{l}\text { Table Concept-Category- } \\
\text { Definition }\end{array}$ & \\
\hline & & & & Diagram of Group Interaction & \\
\hline & & $\begin{array}{l}\text { Selecting Components } \\
\text { of Virtual Workspace }\end{array}$ & $\begin{array}{l}\text { Technique for Association } \\
\text { between Functionalities and } \\
\text { Components (see Table 9) }\end{array}$ & $\begin{array}{l}\text { Table of Association between } \\
\text { Interactions and Functionalities }\end{array}$ & $\begin{array}{l}\text { Table of Association } \\
\text { between Functionalities } \\
\text { and Components }\end{array}$ \\
\hline & & $\begin{array}{l}\text { Modeling of Virtual } \\
\text { Workspace } \\
\text { Architecture }\end{array}$ & $\begin{array}{l}\text { Technique to build Diagram } \\
\text { of Architecture of Virtual } \\
\text { Workspace (see Table 10) }\end{array}$ & $\begin{array}{l}\text { Table of Association between } \\
\text { Functionalities and } \\
\text { Components }\end{array}$ & $\begin{array}{l}\text { Diagram of Architecture } \\
\text { of Virtual Workspace }\end{array}$ \\
\hline
\end{tabular}


Table 2. Technique for Identification of Concepts in Text

\begin{tabular}{ll}
\hline Input: & Description of Work Space (DWS) \\
Output: & List of Concepts \\
\hline Step 1. & Identify persons in DWS \\
Step 2. & Identify objects in DWS \\
Step 3. & Identify actions in DWS \\
Step 4. & $\begin{array}{l}\text { Build a discriminated list of } \\
\text { concepts classifying them in: } \\
\\
\text { actors, objects and actions }\end{array}$ \\
\hline
\end{tabular}

Table 4. Technique to Build Diagram of Cases of Interaction

\begin{tabular}{|c|c|}
\hline Input: & $\begin{array}{l}\text { Table Concept-Category- } \\
\text { Definition }\end{array}$ \\
\hline Output: & Diagram of Cases of Interaction \\
\hline Step 1. & $\begin{array}{l}\text { Identify pairs of actors } \\
\text { interacting }\end{array}$ \\
\hline Step 2 . & $\begin{array}{l}\text { For each pair of actors: } \\
\text { generate a list of objects and } \\
\text { interactions }\end{array}$ \\
\hline Step 3 . & $\begin{array}{l}\text { For each pair of actors: Build } \\
\text { the Case of Interaction }\end{array}$ \\
\hline Step 4 & $\begin{array}{l}\text { For each Case of Interaction: } \\
\text { Give a graphic description in } \\
\text { terms of Actors, Interactions } \\
\text { and Objects }\end{array}$ \\
\hline
\end{tabular}

Table 6. Technique to Build Sequence Diagram Group Dynamics

\begin{tabular}{|c|c|}
\hline Input: & Description of Work Space (DWS) \\
\hline Output: & Diagram of Group Interactions \\
\hline Step 1. & $\begin{array}{l}\text { Deploy the timeline of each } \\
\text { Actor present in Diagram of } \\
\text { Group Interactions }\end{array}$ \\
\hline Step 2 . & $\begin{array}{l}\text { Identify in the DWS, the } \\
\text { sequence of interactions } \\
\text { present in the Diagram of Group } \\
\text { Interactions. }\end{array}$ \\
\hline Step 3. & $\begin{array}{l}\text { For each Interaction in the } \\
\text { Sequence of Interactions } \\
\text { constructed in Step 2, identify } \\
\text { in the DWS: Object present in } \\
\text { the interaction, Actor who } \\
\text { starts Interaction and Actor } \\
\text { who completes Interaction }\end{array}$ \\
\hline Step 4 & $\begin{array}{l}\text { In the Sequence order of } \\
\text { Interactions constructed in } \\
\text { Step 2, deploy interact-tions } \\
\text { with mention to associated } \\
\text { objects identified in step } 3, \\
\text { between timelines of Actors } \\
\text { constructed in Step } 1 \text {. }\end{array}$ \\
\hline Step 5 . & $\begin{array}{l}\text { Identify in the DWS, cycles of } \\
\text { group of interactions and note } \\
\text { them on the constructed } \\
\text { diagram. }\end{array}$ \\
\hline
\end{tabular}

Table 3. Technique to Build Table ConceptCategory-Definition

\begin{tabular}{ll}
\hline $\begin{array}{l}\text { Input: } \\
\text { Output: }\end{array}$ & $\begin{array}{l}\text { Description of Work Space } \\
\text { List of Concepts }\end{array}$ \\
\hline Step 1. & $\begin{array}{l}\text { Categorize Concepts in } \\
\text { Actors (persons), Objects and }\end{array}$ \\
& $\begin{array}{l}\text { Interactions (Actions) } \\
\text { Step 2. }\end{array}$ \\
Step 3. & Integrate results on a Table \\
\hline
\end{tabular}

Table 5. Technique to Build Diagram of Group Interactions

\begin{tabular}{ll}
\hline Input: & Diagram of Cases of Interaction \\
Output: & Diagram of Group Interactions \\
\hline Step 1. & Identify the same Actor (if \\
& exists) in different Cases of \\
& Interaction \\
Step 2. & Initialize Diagram of Group \\
& Interactions with one of Cases of \\
& Interaction identified in 1 \\
Ftep 3. & For each Cases of Interaction not \\
& integrated into the Diagram of \\
& Group Interactions with an Actor \\
& in common with this: integrate the \\
& Case of Interaction with the \\
& common Actor to the Diagram of \\
& Group Interaction \\
& If: Still Exists Cases of \\
& Interaction with a common Actor \\
& but not integrable to the Diagram \\
& of Group Interactions: Initialize \\
a new Diagram of Group \\
Interactions with one of the Cases \\
of Interaction identified. Go to \\
Step 3. \\
otheRwisE: Finish technique \\
execution. \\
For each Diagram of Group \\
Interactions: Give a graphic \\
description in terms of Actors, \\
Interactions and objects \\
Step 5.
\end{tabular}

Table 8. Technique for Association between Interactions and Functionalities

\begin{tabular}{ll}
\hline Input: & $\begin{array}{l}\text { Description of Work Space } \\
\text { Table Concept-Category-Definition } \\
\text { Diagram of Group Interaction }\end{array}$ \\
Output: & $\begin{array}{l}\text { Table of Association between } \\
\text { Interactions and Functionalities }\end{array}$ \\
\hline Step 1. & $\begin{array}{l}\text { Build a table of Interactions } \\
\text { present in the Sequence Diagram of }\end{array}$ \\
& Group Dynamics, distinguishing the \\
& type of interaction. \\
From the Description of Work Space & extend the table developed in Step \\
1, mentioning the functionality \\
which has to be satisfied by \\
componente that will support the \\
associated Interaction. \\
Build a table of Interaction and \\
Component Functionality that will \\
support the Interaction
\end{tabular}


Table 7. Technique to Build Diagram of Conceptual Object Development

\begin{tabular}{|c|c|}
\hline Output: & $\begin{array}{l}\text { Description of Work Space } \\
\text { Table Concept-Category-Definition } \\
\text { Sequence Diagram Group Dynamics } \\
\text { Diagram of Conceptual Object } \\
\text { Development }\end{array}$ \\
\hline Step 1. & $\begin{array}{l}\text { From Table Concept-Category- } \\
\text { Defining, build a table of } \\
\text { Interactions and objects presents } \\
\text { in Diagram of Group Interaction }\end{array}$ \\
\hline Step 2 . & $\begin{array}{l}\text { From the Description of Work Space } \\
\text { and table generated in Step } 1 \text { : } \\
\text { build a table in which objects and } \\
\text { Derived objects are distinguished. } \\
\text { It has to be mentioned the object } \\
\text { from which the derived object } \\
\text { derives, the Interaction which } \\
\text { generates the derived object and } \\
\text { the vinculation of derivation. }\end{array}$ \\
\hline Step 3 . & $\begin{array}{l}\text { From the Description of Work } \\
\text { Space, Table Concept-Category- } \\
\text { Definition, Sequence Diagram Group } \\
\text { Dynamics and the table generated } \\
\text { in step 1: build a table following } \\
\text { the order that describes the } \\
\text { Sequence Diagram of Group } \\
\text { Dynamics, identify: interactions, } \\
\text { transformations associated with } \\
\text { the interactions which object or } \\
\text { objects are inputs of } \\
\text { transformation, objects generated } \\
\text { by each transformation, and cycles } \\
\text { of transformation associated } \\
\text { cycles of interaction. }\end{array}$ \\
\hline Step 4 . & $\begin{array}{l}\text { From tuples (ASSOCIATED } \\
\text { TRANSFORMATION / INPUT OBJECT / } \\
\text { GENERATED OBJECT) described in } \\
\text { table generated in Step } 3 \text { : deploy } \\
\text { the Elemental Components of } \\
\text { Diagram of object Conceptual } \\
\text { Development. }\end{array}$ \\
\hline Step 5 . & $\begin{array}{l}\text { Build Diagram of Conceptual object } \\
\text { Development by coupling Elemental } \\
\text { Components built in } 4 .\end{array}$ \\
\hline
\end{tabular}

Table 9. Technique for Association between Functionalities and Components

\begin{tabular}{ll}
\hline Input: & $\begin{array}{l}\text { Table of Association between } \\
\text { Interactions and Functionalities }\end{array}$ \\
Output: & $\begin{array}{l}\text { Table of Association between } \\
\text { Functionalities and Components }\end{array}$ \\
\hline Step 1. & $\begin{array}{l}\text { Build a table of Interactions } \\
\text { present in the Sequence Diagram }\end{array}$ \\
& of Group Dynamics, distinguishing \\
& the type of interaction. \\
Step 2. & From the Description of work \\
& Space extend the table developed \\
& in Step 1, mentioning the \\
& functionality which has to be \\
& satisfied by componente that will \\
support the associated \\
Interaction. \\
Build a table of Interaction and \\
Component Functionality that will \\
support the Interaction
\end{tabular}

Table 10. Technique to build Diagram of Architecture of Virtual Workspace

\begin{tabular}{|c|c|}
\hline Input: & $\begin{array}{l}\text { Table of Association between } \\
\text { Functionalities and Components } \\
\text { Diagram of Group Interactions }\end{array}$ \\
\hline Output: & $\begin{array}{l}\text { Diagram of Architecture of } \\
\text { Virtual Workspace }\end{array}$ \\
\hline Step 1 & $\begin{array}{l}\text { Deploy Actors present in the } \\
\text { Diagram of Group Interactions }\end{array}$ \\
\hline Step 2 . & $\begin{array}{l}\text { Deploy Components present in the } \\
\text { Table of Association between } \\
\text { Functionalities and Components }\end{array}$ \\
\hline Step 3 . & $\begin{array}{l}\text { Link the Actors and Components } \\
\text { through the Components } \\
\text { Integration System }\end{array}$ \\
\hline
\end{tabular}

\section{Concept Proof}

To illustrate the proposed techniques applied to the development of each task is provided a proof of concept based on a case brought in [3]. The descriptions of the interactions among persons in virtual space that will be designed are presented in the following paragraph:

"...Master's degree student sends the PhD degree student, his master's thesis plan developed previously. PhD degree student reviews the plan and made the corrections and comments that he considers relevant and then send them to master's degree student. He appropriates the corrections and comments to continue working on his master's thesis plan. Once the PhD degree student believes that the version of the master's thesis plan has not problems, forward it to senior researcher asking for his overseeing of the final version of master's thesis plan. Senior researcher oversees the corrections made by the PhD degree student. As a result of overseeing, he can send comments which may include observations about the correction made and/or to make further corrections to be introduced in master's thesis plan. Upon receiving these comments, the PhD degree student appropriates these and forwards them to master's degree student for his appropriating also, allowing in this way the generation of new versions of the document ...". 
The Technique for Identification of Concepts in Text is applied to develop the task of Identification of Concepts, which produces partial conceptualization model (hereinafter PCM) shown in Table 11. The Technique to Build Table ConceptCategory-Definition is applied to develop the task of Categorization and Definition of Concepts, which produces PCM shown in Table 12. The Technique to Build Diagram of Cases of Interaction is applied to develop the task of Identification of Cases of Interaction, which produces PCM shown in Figure 2. The Technique to Build Diagram of Group Interactions is applied to develop the task of Modelling of Group Interaction, which produces PCM shown in Figure 3. The Technique to Build Sequence Diagram Group Dynamics is applied to develop the task of Modelling of Sequence of Group Dynamics, which produces PCM shown in Figure 4.

Table 11. List of Concepts of case "Review of Master's Thesis Plan"

\begin{tabular}{ll}
\hline Concept & Category \\
\hline INCORPORATE & ACTION \\
PhD STUDENT & PERSON \\
SEND & ACTION \\
SEND COMMENTS & ACTION \\
SEND CORRECTION & ACTION \\
SENIOR RESEARCHER & PERSON \\
MASTER STUDENT & PERSON \\
THESIS PLAN & OBJECT \\
REVIEW & ACTION \\
REVIEW AND CORRECT & ACTION \\
REQUEST OVERSEE & ACTION \\
OVERSEE & ACTION \\
\hline
\end{tabular}
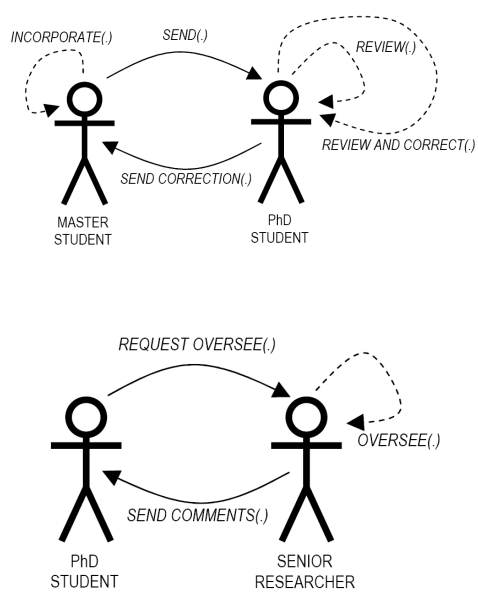

Fig. 2. Interaction cases of concept proof case
Table 12. Table Concept-Category-Definition of case "Review of Master's Thesis Plan"

\begin{tabular}{|c|c|c|}
\hline Concept & Category & Definition \\
\hline INCORPORATE & INTERACTION & $\begin{array}{l}\text { Actor "A" incorporates the received } \\
\text { information in the document and / or } \\
\text { comments in it. }\end{array}$ \\
\hline PhD STUDENT & ACTOR & $\begin{array}{l}\text { Professional who has a master degree or } \\
\text { academic equivalent and is making a career } \\
\text { of doctoral degree }\end{array}$ \\
\hline SEND & INTERACTION & $\begin{array}{l}\text { Actor "A" sends to actor "B" a document or } \\
\text { information. }\end{array}$ \\
\hline $\begin{array}{l}\text { SEND } \\
\text { COMMENTS }\end{array}$ & INTERACTION & $\begin{array}{l}\text { Actor "A" sends Actor "B" the comments on } \\
\text { the results of overseeing carried out, this may } \\
\text { include observations about the correction } \\
\text { made and/or further corrections to make. }\end{array}$ \\
\hline $\begin{array}{l}\text { SEND } \\
\text { CORRECTION }\end{array}$ & INTERACTION & $\begin{array}{l}\text { Actor" A" sends to actor "B" the result of the } \\
\text { review and correction of the document with } \\
\text { its observations. }\end{array}$ \\
\hline $\begin{array}{l}\text { SENIOR } \\
\text { RESEARCHER }\end{array}$ & ACTOR & $\begin{array}{l}\text { Professional with a } \mathrm{PhD} \text { degree or academic } \\
\text { equivalent, with background in human } \\
\text { resources training at the doctoral level and } \\
\text { master degree. }\end{array}$ \\
\hline $\begin{array}{l}\text { MASTER } \\
\text { STUDENT }\end{array}$ & ACTOR & $\begin{array}{l}\text { Professional with grade title and who is } \\
\text { making a master degree }\end{array}$ \\
\hline THESIS PLAN & OBJECT & $\begin{array}{l}\text { Document referred to student's research } \\
\text { project who is carrying out to earn a PhD, } \\
\text { master's, specialty or grade degree. }\end{array}$ \\
\hline
\end{tabular}

REVIEW

INTERACTION

The actor reviews the document and states his comments (in case needed) but without doing any correction.

REVIEW AND INTERACTION CORRECT

REQUEST OVERSEE

INTERACTION

The actor revises and corrects the document with indication of his comments and corrections

Actor "A" asks oversee of review / corrections on a document generated by a third actor. Overseeing will be made by actor "B".

OVERSEE INTERACTION Actor "A" oversees the reviews or corrections made by an actor "B" on a document that has been sent previously to him by a third actor. 
The Technique to Build Diagram of Conceptual Object Development is applied to develop the task of Modeling of Conceptual Object Development, which produces PCM shown in Figure 5.

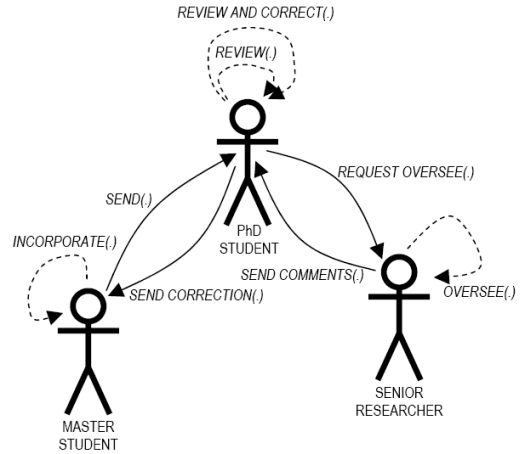

Fig. 3. Group interaction diagram among Actors

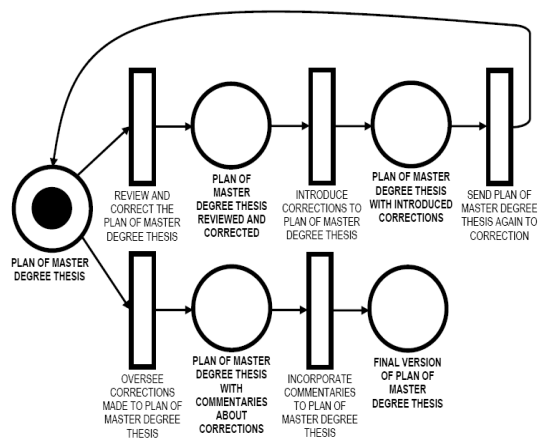

Fig. 5. Diagram of Conceptual Object Development for case "Review of Master's Thesis Plan

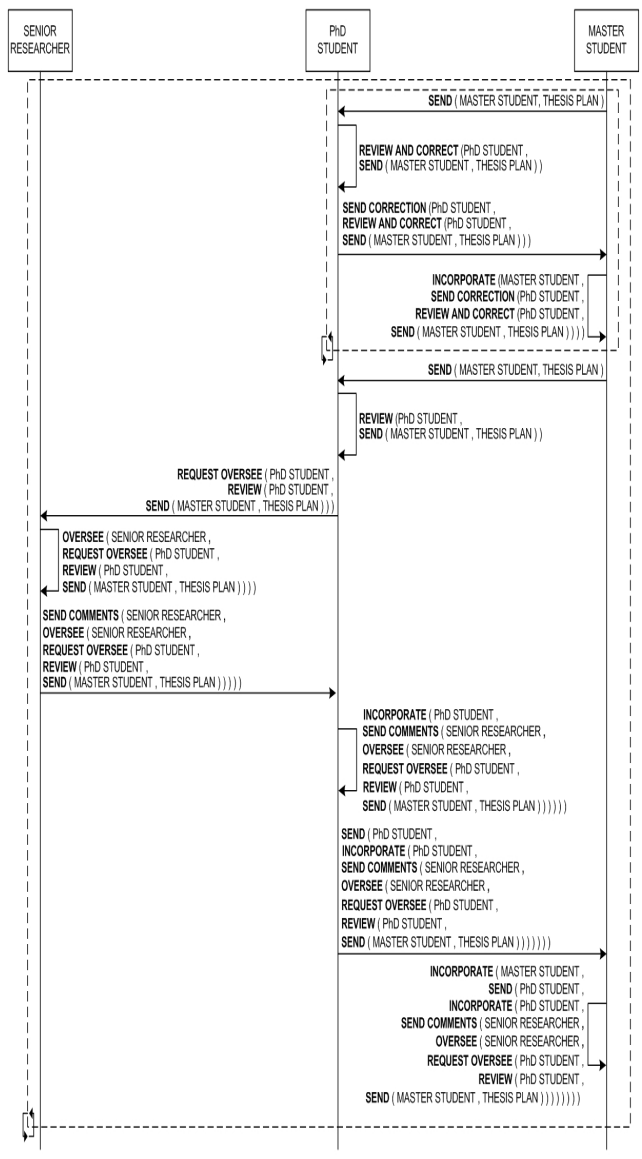

Fig. 4. Sequence Diagram of Group Dynamics of case "Review of Master's Thesis Plan

The Technique for Association between Interactions and Functionalities is applied to develop the task of Specification of Functionalities which produces PCM shown in Table 13. The Technique for Association between Functionalities and Components is applied to develop the task of Selecting Components of Virtual Workspace which produces PCM shown in Table 14. The Technique to build Diagram of Architecture of Virtual Workspace is applied to develop the task of Modelling of Virtual Workspace Architecture which produces PCM shown in Figure 6. 
Table 13. Table of Association between Interactions and Functionalities

\begin{tabular}{|c|c|}
\hline INTERACTION & $\begin{array}{l}\text { FUNCTION- } \\
\text { ALITY }\end{array}$ \\
\hline INCORPORATE & \multirow{3}{*}{$\begin{array}{l}\text { No } \\
\text { component } \\
\text { required }\end{array}$} \\
\hline $\begin{array}{l}\text { REVIEW AND } \\
\text { CORRECT } \\
\end{array}$ & \\
\hline REVIEW & \\
\hline SEND & \multirow{3}{*}{$\begin{array}{l}\text { Ability to } \\
\text { transmit } \\
\text { documents in } \\
\text { real time }\end{array}$} \\
\hline $\begin{array}{l}\text { SEND } \\
\text { COMMENTS }\end{array}$ & \\
\hline $\begin{array}{l}\text { SEND } \\
\text { CORRECTION }\end{array}$ & \\
\hline $\begin{array}{l}\text { REQUEST } \\
\text { OVERSEE }\end{array}$ & \multirow{2}{*}{$\begin{array}{l}\text { Carry video } \\
\text { conferences } \\
1-1\end{array}$} \\
\hline OVERSEE & \\
\hline
\end{tabular}

Table 14. Table of Association between Functionalities and Components

\begin{tabular}{|l|l|}
\hline $\begin{array}{l}\text { COMPONENT } \\
\text { FUNCTION- } \\
\text { ALITY }\end{array}$ & COMPONENT \\
\hline $\begin{array}{l}\text { Ability to } \\
\text { transmit } \\
\text { documents in } \\
\text { real time }\end{array}$ & $\begin{array}{l}\text { EMAIL } \\
\text { MODULE }\end{array}$ \\
\hline $\begin{array}{l}\text { Carry video } \\
\text { conferences 1- } \\
1\end{array}$ & $\begin{array}{l}\text { WEB- } \\
\text { CONFERENCE } \\
\text { MODULE } \\
\text { PERSON TO }\end{array}$ \\
\hline
\end{tabular}

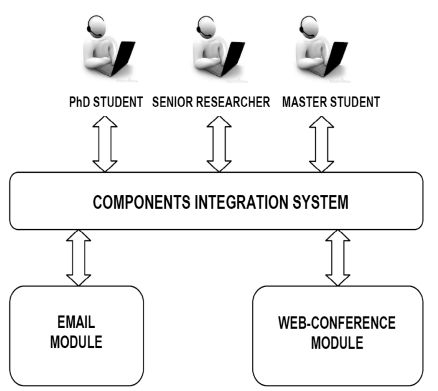

Fig. 6. Diagram of Architecture of Virtual Workspace

\section{Conclusions}

Work in groups is one of the usual labour strategies that may be mediated by Internet technology. Virtual workspaces arise as a possibility to establish working groups in which persons are not physically contiguous or have difficulty to share the same real space. Our work focuses on conceptualization process for customizable virtual working spaces that require to be strictly adjusted to the needs defined by the nature of task developed by the work group. The proposed process is a step towards formal design of the virtual space architecture in which the virtual work will take place.

To consolidate the results presented in this paper, the following research works have been started up: [a] the development of a prototype configuration of VSCW component-based and a prototype tool to support the process of formalizing interactions, and $[\mathrm{b}]$ explore the validity of the proposed conceptualization process in the following cases: (i) VSCW for Architects team working in building design, and (ii) VSCW for Software Engineers team working in software development.

\section{References}

1. Garrido, J.: AMENITIES: A Methodology for the Development of Cooperative Systems Based on Behavioral Models and Tasks (in Spanish). Thesis, University of Granada (2003)

2. Rubart, J., Dawabi, P.: Towards $U M L-G$ : A UML Profile for Modeling Groupware. In: Haake, J.M., Pino, J.A. (eds.) CRIWG 2002. LNCS, vol. 2440, pp. 93-113. Springer, Heidelberg (2002)

3. Rodriguez, D., Garcia-Martinez, R.: A Proposal of Interaction Modelling Formalisms in Virtual Collaborative Work Spaces. Lecture Notes on Software Eng, vol. 2, pp. 76-80 (2014)

4. Malhotra, A., Majchrzak, A.: Virtual workspace technologies. MIT Sloan Management Review 46, 11-14 (2005) 
5. Molina, A., Redondo, M., Ortega, M.: A Review of Notations for Conceptual Modeling of Groupware Systems. In: Macías, J., Granollers, A., Latorre, P. (eds.) New Trends on Human-Computer Interaction, pp. 1-12. Springer, Heidelberg (2009)

6. Corso, M., Giacobbe, A., Martini, A.: Rethinking knowledge management: the role of ICT and the rise of the virtual workspace. Intl. J. Learning \& Intel. Capital 6, 272-292 (2009)

7. Nunamaker, J., Reinig, B., Briggs, R.: Principles for effective virtual teamwork. Communications of the ACM 52, 113-117 (2009)

8. Rodríguez, D., Bertone, R., García-Martínez, R.: Collaborative Research Training Based on Virtual Spaces. In: Reynolds, N., Turcsányi-Szabó, M. (eds.) KCKS 2010. IFIP AICT, vol. 324, pp. 344-353. Springer, Heidelberg (2010)

9. Hossian, A., García-Martínez, R.: Phases, Activities, and Techniques for a Requirements Conceptualization Process. In: Proceedings 24th Intl. Conf. SEKE, pp. 25-32 (2012) 